\title{
Burial Grounds and Dead Lovers: Places of Interment in the Gothic Modernism of the American South
}

\author{
Arthur Redding \\ York University in Toronto \\ aredding@yorku.ca
}

Received 6 March 2017; accepted 2 October 2017.

\begin{abstract}
In Cities of the Dead, Joseph Roach speculates that "Modernity itself might be understood as a new way of handling (and thinking about) the dead" (1996, p. 48). Roach (following Foucault) argues that a whole array of rationalized spatial practices emerged during the Enlightenment designed to enforce policies of segregation and hygiene, demarcating the social and metaphysical lines that were necessary to distinguish black from white, civilization from nature, citizen from foreigner, past from present, reason from supernatural or folk forms of knowing, and - ultimately - living from dead. In this sense, "gothic" romanticism represented the development of a sort of unnatural chiaroscuro effect, whereby such boundaries and lines of distinction became blurred, where dead flesh becomes re-animated, where corpses risen from graves come to contaminate the spaces of the living. In contradistinction to formations that "view the dead as hermetically sealed off from contemporaneous life, quarantined into the past," gothic cultural productions, as Eric Anderson et al. have argued recently in Undead Souths, reveal "how the dead contain cultural vibrancy in the present" $(2015$, p. 2). This essay, rethinking traditional understandings of "Southern Gothic" by emphasizing the world-making power of the dead, explores texts about burial grounds by modernist writers from the American South, William Faulkner's As I Lay Dying (1930) and Frances Newman's Dead Lovers are Faithful Lovers (1928). En route, I consider Freudian and other understandings of mourning from a spatial perspective, focusing on variously abortive or failed funereal dramas of interment and burial.
\end{abstract}

Keywords: Southern Gothic; corpse bride; modernism; American literature; William Faulkner; Frances Newman. 
We all sleep with the corpses of our dead lovers.

John Dufresne

At the center of the narrative of Faulkner's As I Lay Dying (1930) there is, famously, a gap, a literal hole, a blank, in the text; that hole is the coffin-shaped space of the dead Addie Bundren, a speaking corpse. And not only does this corpse speak, she offers up a theory of language itself, a theory wrought of her own sexual disappointment, her certainty that femininity in general - and motherhood in its cruel particulars - is a trap, wrought too of lust, and sexual infidelity, and terror, and agonizing illness and death. Addie's concept of language has been forged in her bitter confrontation with the hypocrisy and brutality of her husband and others in her family and surrounding community. Addie's is a theory of language that is downright Derridean: a word is "a shape to fill a lack" (Faulkner, 1990, p. 172).

But it is also carnal.

From her coffin, Addie recalls and recounts to us unhappily what occurs between her and her husband "in the nights": "He had a word, too. Love, he called it. But I had been used to words for a long time. I knew that the word was like others: just a shape to fill a lack" (Faulkner, 1990, p. 172). For Addie, such words are empty; language, the language of love, of sexuality, the language of enmity, any language and all languages, are products designed to shield us from a confrontation with the ultimate emptiness that is our own selves. Recalling Shakespeare's Juliet Capulet (another famously dead lover), she meditates on the arbitrariness of her husband's name. The difference from Juliet, of course, is that Addie's feelings run from indifference to contempt:

I would think: Anse. Why Anse. Why are you Anse. I would think about his name until after a while I could see the word as a shape, a vessel, and I would watch him liquefy and flow into it like cold molasses flowing out of darkness into the vessel, until the jar stood full and motionless: a significant shape profoundly without life like an empty doorframe; and then I would think that I had forgotten the name of the jar. (1990, p. 173)

For Addie, "the arbitrariness of the sign" is a problem because of its existential dishonesty, because of its falseness, its deception: language is used not to conceal what is, but what is not; she knows that a word is nothing more than "a shape to fill a lack" because of her body, of her womb, of the emptiness she feels in her marriage: "I would think: the shape of my body where I used to be a virgin is in the shape of a and I couldn't think Anse, couldn't remember Anse" (1990, p. 173).

As those readers who know Faulkner's justly famous fifth novel will remember, the story, told through the voices and perspectives of fifteen different characters, concerns the adventures and perils faced by the Bundren family as they undertake an odyssey to the proper burial grounds of wife and mother, Addie. On their journey, Addie's coffin is threatened by flood and fire. Her body is again violated after death when her troubled youngest son, Vardaman, drills holes in the coffin so that she may breathe. Her mortal remains rot away and she begins to stink; buzzards trail the Bundrens as they bear her corpse across the 
country at the behest of the arrogant, self-pitying, and lazy but stubborn patriarch, Anse. Anse is determined to honor his wife's wishes, to bury her with her own kin, in the county seat, Jefferson. But he has ulterior motives as well, as do all the characters. Addie is, ultimately, buried with a borrowed shovel. Anse, who has stolen his daughter's money (money with which she had hoped to pay for an abortion), obtains a new wife, "a kind of duck-shaped woman all dressed up, with them kind of hardlooking pop eyes like she was daring a man to say nothing" (Faulkner, 1990, p. 260), along with a new set of teeth. With the burial of the first wife, life is, somewhat comically, renewed. The familial and social order, now purged of its contaminating elements - the most troublesome son, Darl, has been confined to the madhouse - is restored. With the proper burial of the dead, the world of the living may be renewed.

What I want to emphasize is the constitutive power of the dead, their capacity to make the world. In particular, I want to stress here two aspects of this constitutive power. First, as Addie has insisted, language is carnal. My stress on the corporeality of the word does not mean that Derrida, in his critique of the metaphysics of presence, is wrong about the priority of writing; it does mean that oral discourse or spirit precedes writing. In Addie's case, it is a dead body that speaks, not a living one. Second, Faulkner is teaching us that mourning (whether it be resolved or not) is not simply a psychic process, even in so-called modern societies. Mourning is geographic; it is carried out as a distinctly spatial practice that involves bearing the dead to her or his "rightful" burial grounds.

To briefly elaborate, in Cities of the Dead, Joseph Roach (1996) speculates that "Modernity itself might be understood as a new way of handling (and thinking about) the dead" (p. 48). Roach (following Foucault) argues that a whole array of rationalized spatial practices emerged during the Enlightenment that were designed to enforce policies of segregation and hygiene. Central to the project of constructing modernity, orchestrated burials and the rationalized mapping and planning of graveyards were part and parcel of a new psycho-geographic regime demarcating the social and metaphysical lines that were necessary to distinguish black from white, civilization from nature, citizen from foreigner, past from present, reason from supernatural or folk forms of knowing, and — ultimately — living from dead. Modern social orders, Roach argues, are orchestrated around the rationalized, proper interment and sequestering of the dead in their "assigned" spaces.

But the dead are seldom content to stay in their graves. That these attempts to sequester the dead in places distinct from the place of the living seldom succeed will come as no surprise to readers of this volume. The gothic formations shortly to be attendant upon Enlightenment, hastily defined, are symptomatic of the failure to properly inter the dead. Here is the critic, Eric Anderson, speaking of undeadness:

Undeadness describes a wide continuum of posthumous phenomena, from funerary rites and mourning practices to the shocking overwhelming affect of terrifying spectacles and posttraumatic flashbacks, to figures from beyond death: ghosts, vampires, zombies, but also corpses unburied, decayed, desecrated, dismembered, yet still filled with life, or a kind of life, be it with the multitude of micro-organisms drawing sustenance from decomposing bodies or the 
psychical afterlife of remembering the dead. This necrological impulse can also incarnate in metaphorical ways in texts that may not feature literal revenants but that present tropes of undeadness. $(2015$, p. 1$)$

In this sense, "gothic" romanticism-Mary Shelley's Frankenstein, for example-represented the development of a sort of unnatural chiaroscuro effect, whereby such lines of distinction became blurred, wherein dead flesh becomes re-animated, where corpses rise from graves to contaminate the spaces of the living. In contradistinction to cultural formations that "view the dead as hermetically sealed off from contemporaneous life, quarantined into the past," gothic cultural productions, as Anderson et al. have argued recently in Undead Souths, reveal "how the dead contain cultural vibrancy in the present" (2015, p. 2).

Ventriloquizing the dead is the most urgent of cultural tasks. I very much believe that the gothic pervades the contemporary moment. In Haints, I argued that contemporary gothic writing has, since the millennium's turn, worked to undo national and progressive American narratives "by excavating alternative histories or ghost stories, by imaginatively summoning into presence those voices and beings that have been sacrificed to the march of progress and the consolidation of American literary and cultural traditions" (Redding, 2011, p. 39). And I have argued in an essay on what I term ethno-gothic (Redding, 2015) that there is - or "are" rather - diasporic gothics occasioned in, by and of the imaginaries of the millions of migrants and refugees that are now wandering the globe. Here, I want only to say a few things about American writing, because my initial source is Faulkner, whose work epitomizes what critics often term "Southern Gothic." I will confine myself to a discussion of two (or three) modernist writers from the American South.

Southern Gothic (sometimes Southern grotesque) is a critical term that traditionally refers to the literature produced by Faulkner and other key modernist writers of what was termed the Southern Literary Renaissance of the 1920s and after. Edgar Allan Poe is generally considered the great predecessor to this tradition; Tennessee Williams is often mentioned as well, along with such luminaries as Flannery O'Connor, Carson McCullers, James Agee, at times, or and, somewhat later, Cormac McCarthy. Faulkner's suggestive observation, in Requiem for a Nun (originally published in 1951) that, in the American South, "the past is never dead. It's not even past" (2011, Act I, scene 3) points to the historical persistence in the region of an array of unresolved crises: of its brutal and still unresolved history of enslavement, Jim Crow, and racial violence; ghosts of the genocidal displacement of indigenous Americans, as critics allied with the New Southern Studies argue; of the deep poverty that ensnared working whites within the neo-feudal system of sharecropping during the long economic reign of King Cotton over vast swaths of the region; of the exploitation of coal miners and rural farmers in the remoteness of Appalachia; of a long history of industrial underdevelopment and the neglect of educational institutions.

More broadly, for many contemporary critics, consequently, it is the long, sad history of racial and economic injustice (in the South, and elsewhere) that forms the contours of a specifically American gothic writing, and increasingly, cultural historians have articulated the centrality of American Gothic. The critic Justin Edwards, for example, who connects 
American gothic writing with Freud's theory of the uncanny and with the repressed history of racial "miscegenation" in American life, writes that "there is a sense of strangeness when the unfamiliar appears at the center of the familiar" (2003, p. xxv). And for Teresa Goddu, in Gothic America (1997), as for Kathleen Brogan in Cultural Haunting (1998), homage to the dead is central to the project of American renewal. Brogan points to unsuccessful rituals of burial and to Freud's assessment of melancholia as an unresolved act of mourning on the part of various racialized or minority or immigrant social communities across the new world, who have been violently severed from their pasts or traditions via subjugation, genocide, enslavement, or displacement. Goddu states categorically:

The American Gothic is most recognizable as a regional form. Identified with gothic doom and gloom, the American South serves as the nation's "other," becoming the repository for everything from which the nation wishes to dissociate itself. The benighted South is able to support the irrational impulses of the gothic that the nation as a whole, born of Enlightenment ideals, cannot. (1997, p. 3)

In their introduction to the very new Palgrave Handbook of Sothern Gothic, Charles Crow and Susan Castillo Street concur:

Indeed, the South is a region that has always been obsessed with crossroads and boundaries, whether territorial (the Mason-Dixon line) or those related to gender, social class, sexuality and particularly race. In the South, ghosts and men in white sheets are real, as are shackles and clanking chains, and the Southern Gothic is a genre that arises from the area's often violent and traumatic history. (2016, p. 2)

So too Patricia Yaeger (2000), who in a now classic study that surveys writing from the South by both white and African American women, finds that the racial divide also functions as a kind of mirror, through which when we look, Freud says, we see an alienating figure that turns out to be ourselves. Noting the striking similarities in narratives by southern women writers of different racial backgrounds, Alice Walker and Kate Chopin, Yaeger points to a "haunting in the world of common reality - a world of striking gender inequality, a world unevenly shared by the two races. . . both Chopin [in "Désirée's Baby" 1894] and Walker [in The Third Life of Grange Copeland (1988)] invent heroines who respond to racism by destroying themselves and 'becoming' a landscape" (Yaeger, 2000, p. 43).

In Chopin and Walker, women whose agency threatens the social are killed off. This observation leads me back to Faulkner's Addie Bundren. As a cynic and a non-believer, Addie is condemned for the "sin" of being un-Christian. She confesses to the reader another infidelity: she has had an affair with the preacher (Wainwright). Women's capacity for agency, sexual, intellectual or otherwise, taboo everywhere, is particularly so in the American South, a society wholly dedicated to the cult of femininity, to preserving the imagined virtue of white womanhood. This is why there is always a "corpse bride" at the heart of the gothic text (Addie, in Faulkner); this is why there are corpses of so many women scattered across the literature of the American South. 
"The death of a beautiful woman is, unquestionably, the most poetical topic in the world," writes Poe, notoriously, in his manifesto, "The Philosophy of Composition," from 1846. The great poet of necrophilia, Edgar Allan Poe, is no doubt key to understanding the Southern Gothic. As Tom F. Wright has argued, Poe's works offer a powerful gothic critique of "nineteenth-century society, its values, contradictions and myths - in their spare glimpses of life below the Mason-Dixon line, but perhaps even more visibly in the seemingly placeless depictions of nightmarish aristocratic landscapes" (2016, p. 10). Wright, somewhat surprisingly, scants Poe's sexual perversions. Perhaps Ishmael Reed's commentary about Poe's sensibility is more to the point. Reed conflates Poe's penchant for necrophilia, his fear of premature entombment, and his insistence that there is nothing more sublime than the corpse of beautiful girl with the Civil War and with racial pathologies of American history:

Why isn't Edgar Allan Poe recognized as the principle biographer of that strange war? Fiction, you say? Where does fact begin and fiction leave off? Why does the perfectly rational, in its own time, often sound like mumbo-jumbo? Where did it leave off for Poe, prophet of a civilization buried alive, where according to witnesses, people were often whipped for no reason? Will we ever know, since there are so few traces left of the civilization the planter's called "the fairest civilization the sun ever shown upon," and the slaves called "Satan's kingdom." Poe got it all down. Poe says more in a few stories than all of the volumes by historians. (1976, pp. 18-19)

The quotation is from Reed's satirical novel, Flight to Canada, which was published during the United States' bicentennial year, 1976, and which refigures both Harriet Beecher Stowe's Uncle Tom's Cabin (1852) and the tradition of American slave narratives. Reed's hoodoo revision and interrogation of the American mythmaking apparatus gauges the reciprocal interpenetration of fact and fiction, assessing the productive capacities of literature, its often magical world-making powers, to use the terms of Djelal Kadir. In his discussions of World Literature, Kadir points out that we can take the term "world" as a verb: literature worlds, and, consequently, the critic's task is to "world" literature, "to give it," as Kadir writes, "a particular historical density" (2004, p. 2). Kadir, who elsewhere commends Poe for providing in his writing "an ironically inadvertent replication of America's political unconscious" (2010, p. 18), would agree with Reed that "Poe says more in a few stories than all of the volumes by historians" (1976, p. 19). Poe is in that sense a southern writer; the American South produces Edgar Allan Poe. Poe excavates the political unconscious of the American South - they are mutually constitutive.

There is a deep connection, then, in the deep imaginary of the American South, between places - the land - and corpses, particularly the corpses of brides. Yaeger notes the recurrent image of women's grotesque or monstrous or monstrously large bodies in southern women's writing, theorizing perceptively that, via the cult of womanhood, the white woman's body - and the necessity to protect it from assault — forms the core of the mythic "self-definition" of the American South; thus the "corpse/woman" is subject to all manner of regulation and (quite literally) restraint; in this sense the control of women becomes the very mechanism for control over modern regimes of segregation. Yaeger writes: 
the racially pure and diminutive female body in need of protection becomes the motive force, the purported source for the taboo against race-mixing. As southern myth, this fragile white body helps motivate (1) southern modes of population control, reproducing black and white populations as separate, (2) the regulated segregation of these bodies in space, and (3) the need for deeply interiorized categories of racism that will do the work of segregation. In other words, the small compass of the ideal white woman's body is oddly at war with its epic stature in the minds of white men. This fragile white body, slim as a reed and graceful as a sylph, becomes pivotal in each crucial task of bodily discipline. (2000, p. 120).

To conclude, I want to look briefly at another text, about a similar journey-the journey of the corpse in its coffin, which is being taken by the surviving spouse from the place of death to its burial at home. The book is titled, with some resonance, Dead Lovers are Faithful Lovers, written by another southern writer, the feminist modernist Frances Newman, and published in 1928, two years before As I Lay Dying. Newman is largely forgotten today, even by revisionist critics with feminist sensibilities - some attention paid by feminist historians in the 1980s and 1990s, when my edition was printed. Barbara Ann Wade published a biography in 1998, but there has been almost nothing since then. Newman does not even merit a mention in Yaeger's great survey of southern women's writing, Dirt and Desire. To be fair, Yaeger's study covers works from 1930 - two years after Newman's deathto 1990 , but even so, it seems an oversight. But Faulkner doubtless would have known the text - this, along with Newman's first novel, The Hard-Boiled Virgin (originally published in 1926), both sharply barbed satirical attacks on the sexual customs and rigid social hierarchies of the American South, caused quite a scandal upon their publication. The novel, however, is hardly gothic. Newman's style is arch, elegant, modernist; the stream of consciousness technique is more reminiscent of Virginia Woolf or (in its pointed repetitions and sexually comic irony) even Gertrude Stein than it is of Faulkner, though Newman is capable, in this book, of shifting points of view in as jarringly smooth a fashion as Faulkner became famous for. The critic and doyen of the southern agrarians, Donald Davidson, lamented that her writing too closely resembled "defeated Europeans like Joyce and jabbering expatriates like Gertrude Stein” (as cited in Jones 1994, pp. viii-ix).

Like As I Lay Dying, Dead Lovers tells the story of a love triangle: the well-born Evelyn Cunningham remains passionately in love with her husband, Charlton, but risks losing him to the seductive temptations of a rival, Isabel Ramsay. Evelyn is a highborn aristocrat, of an old and highly respectable southern family; she marries Charlton, executive for the Southeast railroad, thus wedding the prestige of her family to the newly industrializing and capitalist South. Isabel Ramsey is, by contrast, a new woman, a jazz age flapper, employed as a librarian, and an intellectual: she reads Eliot's "The Waste Land" in 1922, the year it is published, and is constantly trying to impress on her library patrons the importance of such new writings as those of Joyce or Fitzgerald. Though we never enter inside Charlton's head, he wavers between the wife and the mistress, each of whom lays competing symbolic claims over the twentieth-century American (his name is evocative of the city of Charleston, in South Carolina). Among Newman's many sly ironies in this novel, however, is that neither of the women is content to be rendered as "symbol," much less as a gothic victim 
or villain. As Anne Goodwyn Jones notes in the foreword to the 1994 edition of the novel, "the minds of [Newman's] urban are intricate, complicated, informed, careful, in a word urbane - much like their social South, and Newman's style" (1994, p. xxvii). Among its other subversions, this book takes readers inside the minds of both the modern new woman and the grand belle of the old South, both of whom are articulate, unbowed, assertive, sexual, and self-conscious about their passions. Neither will submit, neither will surrender. Evelyn, for example, suffers the disconnect between her sexual and emotional passion and the very social ideals to which her rank and position and gender yoke her:

Evelyn Cunningham lay down on her yellow chaise longue [sic] and shut her eyes. She pressed a hot cheek against the cold right hand which was holding her warm right shoulder, and she let her cold left hand press its fingers around her warm right breast.

She still felt that her whole life was beating against her arms. And she felt that a little echo was beating against the back of the left hand which was touching her throat, and that a terrifying conviction was flying down to strike against her tired mind - a conviction that she already loved her husband more than he loved her.

Another conviction flew down and struck against the mind that already felt full and tight like an aching tooth. And she began to be afraid that Charlton Cunningham might have begun to love her in the gold and scarlet glamour of the homage which had painted the footlights of the beautifully set stage where he had first seen her, and that she could not make scarlet and gold footlights for herself on this narrow new stage, and that she might live long enough to die on the day when he did not love her at all. (1994, pp. 45-46)

So, what will happen? Two passionate lovers, one man. Against expectations, against gothic conventions, the plot is resolved when Charlton sickens and dies. At the center of this novel is the corpse of a beautiful young man. Again, taking his cue, Faulkner will famously invert the same set of expectations in his acerbic portrait of the necrophiliac Emily Grierson, in his much anthologized "A Rose for Emily," first published in The Forum in 1930.

The corpse groom does not speak. It is his body that is being conveyed from his deathbed in New York to his burial ground in Atlanta, via a private railroad carriage: as Aristocrats, the Cunninghams (dead and alive) travel in more elegant style than do the Bundrens. We witness, in the final episode of the novel, Evelyn Cunnigham carefully dressing herself in widow's black; her widowhood secures her victory over her rival, even as it secures and cements her social status, as Poe's raven would say, forevermore. However comic or ironic her vision, Newman knows the old South will never succumb to the seductions of the modern. We see Evelyn descend, regally, in mourning, as the train arrives in Atlanta, "as she lifted her hand to her little hat, it did not tell her that she felt herself walking at last on the green oasis of a memory over which she was dropping the victorious curtain of her very long black crape veil" (1994, pp. 294-295).

And where does that leave the dead to rest? Ultimately, they go to rest with us. 


\section{References}

Anderson, E. G., Hagood, T., \& Turner, D. C. (2015). Undead Souths: The Gothic and beyond in southern literature and culture. New Orleans: Louisiana State University Press.

Bradbury, J. M. (1963). Renaissance in the South: A critical history of the literature, 1920-1960. Chapel Hill: University of North Carolina Press.

Brogan, K. (1998). Cultural haunting: Ghosts and ethnicity in recent American literature. Charlottesville: University of Virginia Press.

Crow, C. L., \& S. Castillo Street (Eds.), 2016. The Palgrave handbook of the Southern Gothic. London, UK: Palgrave Macmillan.

Dufresne, J., \& Wade, J. M. (2013, August 22). The Rumpus interview with John Dufresne. The Rumpus. Retrieved August 20, 2016 from: http://therumpus.net/2013/08/the-rumpus-interview-withjohn-dufresne/

Edwards, J. D. (2003). Gothic passages: Racial ambiguity and the American Gothic. Iowa City: University of Iowa Press.

Faulkner, W. (1990). As I lay dying. New York, NY: Vintage.

Faulkner, W. (2011). Requiem for a nun. New York, NY: Knopf.

Goddu, T. (1997). Gothic America: Narrative, history, and nation. New York, NY: Columbia University Press.

Jones, A. G. (1994). Introduction. In F. Newman (Ed.), Dead lovers are faithful lovers (pp. iv-xxxvi). Athens: University of Georgia Press.

Kadir, D. (2004). To world, to globalize: Comparative literature's crossroads. Comparative Literature Studies, 41.1, 1-9.

Kadir, D. (2010). Edgar Allan Poe: America's conscience and epistemic anxiety. In L. Juárez (Ed.), Poe alive in the century of anxiety (pp. 17-30). Madrid, Spain: Instituto Benjamin Franklin.

Newman, F. (1926). The hard-boiled virgin. New York, NY: Boni \& Liveright.

Newman, F. (1994). Dead lovers are faithful lovers. Athens: University of Georgia Press.

Poe, E. A. (1946). The philosophy of composition. Retrieved February 28, 2017 from: http://www.bartleby.com/109/11.html

Redding, A. (2011). "Haints": American ghosts, millennial passions, and contemporary Gothic fiction. Tuscaloosa: University of Alabama Press.

Redding, A. (2015). Ethno-Gothic: Repurposing genre in contemporary American literature. In J. Haslam \& J. Faflak (Eds.), American Gothic culture: An Edinburgh companion (pp. 60-76). Edinburgh, UK: Edinburgh University Press.

Roach, J. (1996). Cities of the dead: Circum-Atlantic performance. New York, NY: Columbia University Press.

Reed, I. (1976). Flight to Canada. New York, NY: Random House. 
Wade, B. A. (1998). Frances Newman: Southern satirist and literary rebel. Tuscaloosa: University of Alabama Press.

Wright, T. F. (2016). Edgar Allan Poe and the Southern Gothic. In C. Crow \& S. Castillo Street (Eds.), The Palgrave handbook to Southern Gothic (pp. 9-20). London, UK: Palgrave Macmillan.

Yaeger, P. (2000). Dirt and desire: Reconstructing Southern women's writing, 1930-1990. Chicago, IL: University of Chicago Press. 